\author{
BULETINUL INSTITUTULUI POLITEHNIC DIN IAŞI \\ Publicat de \\ Universitatea Tehnică „Gheorghe Asachi” din Iaşi \\ Volumul 67 (71), Numărul 1, 2021 \\ Secţia \\ ELECTROTEHNICĂ. ENERGETICĂ. ELECTRONICĂ \\ DOI:10.2478/bipie-2021-0001 \\ sciendo
}

\title{
BROADBAND DIELECTRIC SPECTROSCOPY AND ITS ROLE IN THE CHARACTERIZATION OF BIOLOGICAL CELLS
}

BY

\author{
THOMAS GABRIEL SCHREINER ${ }^{1,2, *}$ and MARICEL ADAM ${ }^{2}$ \\ ${ }^{1}$ University of Medicine and Pharmacy “Gr. T. Popa” Iași, Romania \\ 2"Gheorghe Asachi" Technical University of Iaşi, Romania
}

Received: September 13, 2021

Accepted for publication: October 15, 2021

Abstract. Broadband dielectric spectroscopy (BDS) is a method of characterizing matter from the perspective of its dielectric parameters, which varies depending on the frequency of the applied electromagnetic field. During recent years, along with its many uses, there has been an increase in interest in the use of the method in biomedical fields, especially for the characterization of normal and tumor cells. In this context, this review aims to address in the first part the theoretical bases and mathematical models that explain the principle of operation of the broadband spectroscope. Subsequently, the advantages and limitations of the method are detailed, including the difficulties that the researcher may encounter in the case of working with living cells. Finally, the most important scientific results obtained on normal and pathological cell cultures are presented, possible future research directions being suggested.

Keywords: Broadband dielectric spectroscopy; tumor cells; dielectric parameters; spectrometer; Nyquist plot.

\footnotetext{
*Corresponding author; e-mail: schreiner.thomasgabriel@yahoo.com (C) 2021 Thomas Gabriel Schreiner and Maricel Adam

This is an open access article licensed under the Creative Commons Attribution-NonCommercialNoDerivatives 4.0 International License (CC BY-NC-ND 4.0).
} 


\section{Introduction}

Broadband dielectric spectroscopy (BDS), a subtype of impedance spectroscopy, is a method used for the detection and characterization of different types of material, from inorganic components to organic substances and living cells (Kremer, 2002). Successfully implemented during the last century, this method has returned into the attention of researchers in recent years, especially if we refer to the study of tumor cells, as determining dielectric parameters in cancerous cells may open new ways of early cancer detection or disease monitoring after a certain treatment (Nasir and Al Ahmad, 2020).

There are many areas in which BDS, having multiple applications, already plays an important role. The potentially huge role of BDS in agricultural sciences was mentioned by Nelson since 2004, when describing the possibility of sensing of maturity or other quality factors in fruits and vegetables with the help of this easy-to-use method (Nelson, 2004).

On a large industrial scale, the method is used in different stages of the food quality control process. From the study of the composition of some products such as milk, to the determination of the acidity of the oil or the validity of some food products, BDS plays a crucial role in the prevention of food poisoning.

Also in the case of biosensor systems with different applications, BDS finds its utility, the best example being the label-free method of detection and measurement of highly pathogenic bacterial components (Escherichia coli, Salmonella) from a solution. The work of (Li et al., 2018) showed significant differences between live and heat-killed E. coli, as the conductivity of the heatkilled E. coli cell lysate was $8.22 \%$ lower than that of viable cells. Explained by cell membrane destruction and cytoplasm loss, increased protein diffusivity and ion flow, these results are reproducible also in other pathogens.

\section{Theoretical Background}

The interaction between matter and the electromagnetic field, the key element in the operating principle of the spectroscope, is based on processes such as polarization and relaxation that take place at different structural levels, depending on the frequency of the applied field. We speak of electronic polarization, when there is a movement of electrons around the nucleus in a neutral atom. Comparatively, in atomic polarization there is a reorientation of the nucleus according to the field lines, but smaller compared to electronic polarization.

The frequency is the main dictator for the relaxations that take place at ionic, atomic or electronic level, as there are specific frequency bands for each type of relaxation. In BDS, the working frequencies vary between $102-1010 \mathrm{~Hz}$, the phenomenon that occurs is called dielectric relaxation. It represents the 
delay of molecular polarization and, in practice, it is described in terms of frequency-dependent permittivity, described by the Debye equation in the case of an ideal system.

In this model introduced by Peter Debye in 1913, the complex permittivity of the environment depends on the angular frequency of the field and the relaxation time according to Eq. (1.a.) (the permittivity equation), (1.b.) and (1.c.) the real and imaginary parts of the permittivity respectively.

$$
\begin{aligned}
& \hat{\varepsilon}(\omega)=\varepsilon_{\infty}+\frac{\Delta \varepsilon}{1+i \omega \tau} \\
& \varepsilon^{\prime}=\varepsilon_{\infty}+\frac{\varepsilon_{S}-\varepsilon_{\infty}}{1+\omega^{2} \tau^{2}} \\
& \varepsilon^{\prime \prime}=\frac{\left(\varepsilon_{S}-\varepsilon_{\infty}\right) \omega \tau}{1+\omega^{2} \tau^{2}}
\end{aligned}
$$

The parameters of interest, especially in the case of measurements made on living cells are the following: relative permittivity, dielectric loss factor and conductivity.

Relative electrical permittivity, a dimensionless parameter, describes the polarization of a material and is obtained from a ratio of the absolute capacitances or permittivities of the material and the vacuum. The range of values varies from 1 , the small permittivity characterizing materials with insulating properties, while high permittivity is specific for ferroelectrics used in the composition of capacitors. This physical quantity depends on external factors independent of the material, such as temperature, humidity, and the parameters of the applied field, elements that must be taken into account in case of experiments on living cells. Given all these influences on physical size that must be taken into consideration in real situations, the calculation becomes more complicated, the most used formula being the one suggested since 1941 by Cole (Eq. (2)). In this equation, $\varepsilon_{\infty}$ refers to the high frequency permittivity, $\omega$ is the angular frequency, $\Delta$ - the modification of the permittivity for each dispersion identified by the subscript $\mathrm{i}$, be the relaxation frequency corresponding to the maximum value of the imaginary part of the permittivity and $\sigma$ conductivity. The parameter $\alpha$ is a number between 0 and 1 .

$$
\varepsilon^{*}=\varepsilon_{\infty}+\sum_{i} \frac{\Delta E_{i}}{1+\left(j \omega \frac{1}{f_{i}}\right)^{1-\alpha}}-\frac{j \sigma}{\omega \varepsilon_{0}}
$$

(Calculating permittivity after (Cole and Cole, 1941) formula)

Dielectric loss, also known as the dissipation factor, illustrates the property of a material to lose / dissipate energy. Being quantified as loss angle $\delta$ or the corresponding loss tangent $\tan \delta$, this parameter is a ratio between the real 
and the imaginary part of the permittivity (Eq. (3)). Ideally, this energy loss should be as small as possible, but in the case of living cells, it remains a variable parameter that depends on the type of tissue and the presence or absence of malignancy.

$$
\tan (\delta)=\frac{\varepsilon^{\prime \prime}}{\varepsilon^{\prime}}=\frac{\left(\varepsilon_{S^{-}} \varepsilon_{\infty}\right) \omega \tau}{\varepsilon_{S}+\varepsilon_{\infty} \omega^{2} \tau^{2}}
$$

Conductivity, the opposite parameter to resistivity, characterizes the ability of a material to conduct electrical current. In the case of living cells, similar to the other parameters mentioned above, determining conductivity depends on the applied theoretical cell model.

In the case of cells, in order to establish a mathematical model, it is necessary to first mention the fact that these organic components are not homogeneous. Thus, a simplified, reductionist model of the cell was initially proposed, in which only the presence of the external membrane and the internal cytoplasm were taken into account from an electrical point of view. Called single-shell cell model, the cell is represented through a sphere with a certain radius R1 (inner radius) and R2 (outer radius with membranes), without nucleus or other cellular organs, having only a membrane of a certain thickness that is characterized by electrical sizes separated by content. Although simpler for calculations, the model is imperfect, incomplete and imprecise, because it does not take into account the intracellular organs that modify the dielectric parameters. Therefore, for a better accuracy of the results and a more accurate simulation of the biological reality, scientists opted for the dual-shell model. In this case, along with the plasma membrane, there is also an internal membrane that simulates the existence of the cell nucleus, being one step closer to the real living cell. This model is not perfect either, in the sense that cellular organs are not taken into account and the plasma is considered homogeneous throughout its structure, which is true for a small number of cells and inadequate for tumor cells with an irregular, inhomogeneous structure of the cytoplasm and membrane. Finally, in the theoretical way, this dual-shell model can be extended in complexity and number of membranes, so that for a cell model with $\mathrm{N}$ membranes (multi-shell cell model - Fig. 1), the equation becomes more and more complicated, but with the possibility of simplification up to the reduction to single-shell cell model.

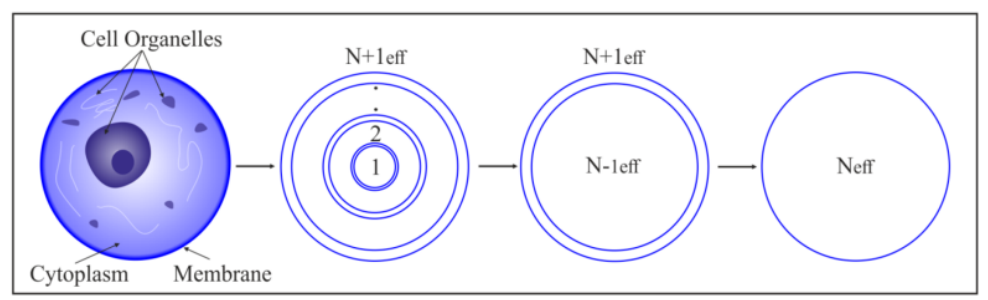

Fig. 1 - Multi-shell cell model (Reprinted from Turcan and Olariu, 2020). 


\section{The Advantages of the Method}

In the case of living cells, the researcher has many methods to characterize them. From light microscopy to transmission- or scanning electron microscopy, including fluorescent or radioactive labeled antibodies, many details about most cell subtypes are currently known. However, many times, these methods are expensive, require special equipment and specialized personnel, and are sometimes difficult to perform on cell cultures sensitive to any external interaction. Thus, BDS can be an interesting alternative method of studying living cells, as this method does not structurally and functionally alter cell viability. Table 1 summarizes the advantages and disadvantages of the method, while making a comparison with the other methods used in the study of cells. BDS has some definite advantages compared to electron microscopy imaging techniques in terms of lower cost and the fact that it remains a nondestructive technique. Besides the fact that there is no need for specific labeled antibodies or other steps in the preparation of the sample, the results are consistent and of a good resolution, if several correct measurements are performed on the same sample.

Table 1

BDS vs. Other Cell Characterization Techniques

\begin{tabular}{|c|c|c|}
\hline Technique & Advantages & Disadvantages \\
\hline BDS & $\begin{array}{ll}\text { - } & \text { Consistent results } \\
\text { - } & \text { Nondestructive } \\
& \text { technique (less material } \\
& \text { required) } \\
\text { - } & \text { Also used in cell sorting } \\
\text { - } & \text { High resolution } \\
\end{array}$ & $\begin{array}{l}\text { - } \quad \text { Few days processing } \\
\text { time } \\
\text { - } \quad \text { Electrode } \\
\text { polarization }\end{array}$ \\
\hline $\begin{array}{l}\text { Optical microscopy } \\
\text { (and subtypes such as } \\
\text { confocal, } \\
\text { fluorescence } \\
\text { microscopy) }\end{array}$ & $\begin{array}{ll}\text { - } & \text { Direct imaging (no } \\
\text { sample pre-treatment) } \\
\text { - } & \text { Fast and adaptable to all } \\
\text { kind of samples } \\
\text { - } & \text { Cheap } \\
\end{array}$ & $\begin{array}{ll}\text { - } & \text { Low resolution } \\
\text { - } & \text { Magnification only } \\
\text { up to } 1000-1500 \mathrm{x} \\
\text { - } & \text { Low depth of field }\end{array}$ \\
\hline $\begin{array}{c}\text { Transmission } \\
\text { Electron Microscopy } \\
\text { (TEM) }\end{array}$ & $\begin{array}{l}\text { - } \begin{array}{l}\text { Powerful magnification } \\
\text { and resolution }\end{array} \\
\text { - } \begin{array}{l}\text { Provides information on } \\
\text { element and compound }\end{array} \\
\text { structure } \\
\text { - High-quality images }\end{array}$ & 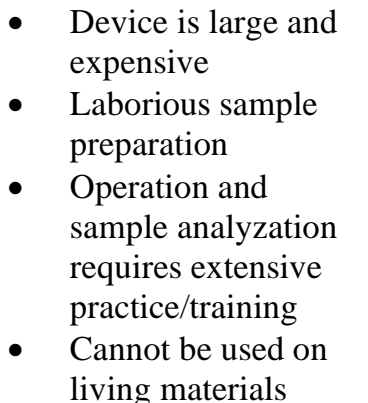 \\
\hline
\end{tabular}




\begin{tabular}{|c|c|c|}
\hline $\begin{array}{l}\text { Scanning Electron } \\
\text { Microscopy (SEM) }\end{array}$ & $\begin{array}{ll}\text { - } & \text { Possibility of high in- } \\
\text { depth field } \\
\text { - } & \text { Great Magnification } \\
\text { - } & \text { gower } \\
\text { - } & \text { in digital form } \\
\text { Minimal sample } \\
\text { preparation }\end{array}$ & $\begin{array}{ll}\text { - } & \text { Examination limited } \\
\text { - } & \text { Do solid samples } \\
& \text { Device is large and } \\
\text { - } & \text { Oppensive } \\
& \text { sample analyzation and } \\
\text { requires expertise } \\
\text { - } & \text { Preparation may } \\
& \text { destroy sample } \\
\end{array}$ \\
\hline $\begin{array}{l}\text { Gas chromatography } \\
\text { Mass spectrometry }\end{array}$ & $\begin{array}{ll}\text { - } & \text { Fast analysis } \\
\text { - } & \text { Inexpensive } \\
\text { - } & \text { reliable and relatively } \\
& \text { simple } \\
\text { - } & \text { nondestructive }\end{array}$ & $\begin{array}{ll}\text { - } & \text { limited to volatile } \\
\text { - } & \text { nomples } \\
\text { not suitable for } \\
\text { thermal labile } \\
\text { samples } \\
\text { - } \quad \text { requires additional } \\
\text { sample preparation }\end{array}$ \\
\hline
\end{tabular}

\section{Limitations and Difficulties Faced by the Researcher when Using BDS}

Like any other instrument, BDS has also some weaknesses, being extremely sensitive to external environment influences. Given that temperature and humidity will directly influence the dielectric parameters of the sample, ensuring a controlled environment remains essential for obtaining precise results.

The main problem that arises when using BDS on biological components such as living cells and that influences the measurement is the polarization of the electrode (Emmert et al., 2011). In the case of cells, the measurements conducted with the help of BDS include the manifestation of at least two phenomena: dipolar polarization and Maxwell-Wagner polarization (Turcan and Olariu, 2020). Dipolar polarization, known also as orientation polarization, refers to dipoles and nonlinear dielectrics and represents the rotational movement in electrical field. It is highly dependent to temperature, molecule size and weight. The Maxwell-Wagner polarization on the other hand, is an undesirable phenomenon of electrode polarization occurs at the interface between the material to be investigated (cell suspension) and the electrode, which will cause additional capacitance. Finally, all dielectric parameters of the sample will be modified, knowing elevated values. Of course, this phenomenon is partially reducible, and among the most commonly used methods we list:

- Thorough cleaning of electrodes

- Ensuring that the sample is sterile or as little contaminated as possible

- Performing multiple measurements for the same sample

- Increasing the distance between the electrodes (in the case of the measuring cell with parallel capacitors), obviously with limitations

- Use of a four-wire liquid sample cell 
- In the case of certain spectrometers, there are additional components (analyzers, software) that take into account the polarization of the electrode and reduce measurement errors.

In order to reduce until total cancellation of the electrode polarization, numerous modifications have been tried regarding its design (Havelka et al., 2018). In order to have a chemically inert electrode, either platinum electrodes or platinum-coated electrodes were used, and, in terms of arrangement, four terminal electrode arrangements were chosen. There is a constant concern in this regard, as evidenced by a study conducted by Stoneman (Stoneman et al., 2007), in which the team proposes an innovative design for a platinum black coated platinum coaxial electrode, with an increased capacity, to make measurements as accurate in the range of $40 \mathrm{~Hz}-100 \mathrm{MHz}$. High frequencies themselves are a burden for precise measurement, and the technology must be constantly improved if we consider evaluation of specific biomolecules and other particles / cells at frequencies up to $100 \mathrm{GHz}$ (Laux et al., 2018).

Regarding the strict measurement of dielectric parameters in the case of living cells, difficulties also arise in the preparation of samples. A simple search in the literature shows the possibility of using different types of buffer solutions, some complex that require training in specialized laboratories for sample preparation (Bao et al., 2018). At the same time, each cell line, healthy or malignant has its own characteristics and requirements regarding viability, osmolality, which the suspension solution must meet, otherwise, risking cell death. Finding the ideal buffer solution is a challenge for the researcher, although theoretically this could be achieved by simply getting an equimolecular mixture between a weak acid and the conjugate base, or a weak base with conjugate acid to maintain a constant $\mathrm{pH}$ and add small amounts. from other $\mathrm{pH}$ disturbing substances. In order to reduce polarization or minimize Joule heating effect, buffers with low conductivity are preferred, preferably the conductivity of the solution to be (much) lower than the cellular conductivity (Shiraga et al., 2015).

\section{BDS Applications in the Characterization of Living Cells}

The first research on living matter began in the last century, relevant being the pioneering work led by Schwan (Schwan, 1957). In addition to providing a solid theoretical basis, the author presented the practical results of various measurements performed on blood cells (erythrocyte suspension), cells originating from liver or muscle tissue. In the following years, other experiments were carried out and consisted of different measurements of dielectric characteristics on different types of human, animal and plant tissues, in 1996 appearing one of the most extensive research in this field. The work of Gabriel (Gabriel et al., 1996) remains to this day a far-reaching one and a starting point for the rest of the studies conducted thereafter. In the study, the 
authors compared different tissues from different animal species and normal human cells. Measurements were made in a wide frequency range, from $10 \mathrm{~Hz}$ to $20 \mathrm{GHz}$, at human body temperature. It should be mentioned that spectroscopy revealed differences between species, but also individual variations even for the same tissue. Another peculiarity worth considering is the fact that some tissues change their dielectric characteristics postmortem, following dehydration and fixing the sample for study. Thus, in the case of human or animal adipose tissue we find a great variability on the frequency bands. Similarly, variations occur in the case of bone marrow or cartilage, where two elements are the cause of these various values from individual to individual: the water content of the tissue and its vascularization. Of course, variations in values also occur depending on the direction of application of the electric field, an element observed and carefully noted since the first research conducted with BDS.

In recent years, the method has returned to researchers' attention, more precisely in the field of oncology (Grenier et al., 2013). A first example would be the work of Souli (Souli et al., 2017) who conducted a study on a wide variety of human and mammalian cells in pathological conditions, such as irradiation or cancerous changes. Despite individual variability, significant differences have been established between normal cells and their pathological variants, especially in the case of breast or prostate tissue. Unexpected results have been reported for normal and pathological lung cells, whose dielectric characteristics depend on the results of the long air content working group and the percentage of fat.

Another recent study evaluated the behavior of normal or pathological cells in the breast tissue. Clear differences were observed between healthy and tumor cells in terms of permittivity, and in the case of the latter category, significant differences between primary and metastatic tumor cells (Ambrico et al., 2020). Important differences in electromagnetic field behavior are also recorded in the case of subtypes of human gliomas (Gavdush et al., 2021), Table 2 summarizing the most relevant findings.

The principles of BDS can be used in microfluidic systems, having the role of facilitating the capture of particles of interest for the study. Moving from simple analysis to cell separation and isolation, the perspectives open on a new technique also based on the phenomenon of dielectrophoresis. For example, in the desire to isolate bacteria from a blood sample, (D'Amico et al., 2017) developed a microfluidic dialysis system that, incorporating the principle of different polarization in the electromagnetic field of some bacteria, allowed the separation of E. coli and S. aureus. Subsequently, by PCR testing, the bacterial DNA from the final sample shows that BDS is a feasible technique for characterizing heterogeneous components of a solution, being a first step for separating a mixture into distinct parts. 
Also in the same line with the aforementioned study is a new emerging field of detection of circulating tumor cells (CTCs). Because of their low concentration in peripheral blood and heterogeneous molecular characteristics, BDS is a reliable adjuvant tool in trying to separate CTCs from other blood compounds (Qian et al., 2015). As a result, beside the size and weight differences of CTCs to red and white blood cells, different polarization-induced dielectric forces are useful in making the separation process easier.

Table 2

Most Recent Studies on BDS Utility in Cell Characterization

\begin{tabular}{|c|c|c|}
\hline Cell type & Main findings & Reference \\
\hline $\begin{array}{l}\text { Healthy, cancerous, } \\
\text { and metastatic } \\
\text { adenocarcinoma cells }\end{array}$ & $\begin{array}{l}\text { 1. Larger variation of } \\
\text { capacitance for tumor cells } \\
\text { vs. normal cells } \\
\text { 2. Larger ratio between the } \\
\text { real and imaginary part of } \\
\text { the dielectric permittivity } \\
\text { function for metastatic cells } \\
\text { vs. normal ones }\end{array}$ & (Ambrico et al., 2020) \\
\hline $\begin{array}{c}\text { Brain glioma (WHO } \\
\text { grades I to IV) }\end{array}$ & $\begin{array}{c}\text { Higher refractive index and } \\
\text { absorption coefficient in the } \\
\text { THz range }\end{array}$ & (Gavdush et al., 2021) \\
\hline $\begin{array}{c}\text { Rat tissue } \\
\text { (cerebellum, skin) } \\
\text { Human tissue (lung, } \\
\text { prostate) }\end{array}$ & $\begin{array}{l}\text { 1. Rat skin exposed to } \\
\text { radiation was less } \\
\text { conductive than normal } \\
\text { tissue at ambient } \\
\text { temperature } \\
\text { 2. Healthy human lung tissues } \\
\text { show greater values of } \\
\text { conductivity at } 10^{5} \mathrm{~Hz} \text { than } \\
\text { cancerous ones. } \\
\text { 3. Human prostate cancer } \\
\text { tissue with a Gleason score } \\
\text { of } 6 \text { appears to be more } \\
\text { conductive than the control } \\
\text { ones, while more } \\
\text { aggressive forms of cancer } \\
\text { (Gleason score 8) seem to } \\
\text { be less conductive. }\end{array}$ & (Souli et al., 2017) \\
\hline Human blood & $\begin{array}{l}\text { 1. Absence of an } \alpha \text {-relaxation } \\
\text { in blood } \\
\text { 2. } \beta \text {-relaxation is composed of } \\
\text { two separate relaxation } \\
\text { processes. }\end{array}$ & (Wolf et al., 2011) \\
\hline
\end{tabular}




\section{Conclusions and Future Research Directions}

Given both the current knowledge on BDS and the measurements already performed on a multitude of normal and pathological tissues, it is clear this is a useful technique in cell characterization. Despite its advantages (cheap, nondestructive, high resolution technique), one must acknowledge the limitations of this instrument and the fact that it provides only limited information regarding living cells. Thus, it is still necessary to improve the dielectric spectroscopy systems currently used in order to become basic methods in scientific research and industrial applications.

Acknowledgements. The information contained in this article was also a starting point and inspiration source for author's presentation at the 4th International Conference of the Doctoral School, 19-21 May, 2021, Iași, Romania.

\section{REFERENCES}

Ambrico M., Lasalvia M., Ligonzo T., Ambrico P.F., Perna G., Capozzi V., Recognition of Healthy and Cancerous Breast Cells: Sensing the Differences by Dielectric Spectroscopy, Med Phys., 2020 Oct; 47, 10, 5373-5382, doi: 10.1002/mp.14425.

Bao X., Liu S., Ocket I., Liu Z., Schreurs D.M.M., Nauwelaers B.K.J.C., A Modeling Procedure of the Broadband Dielectric Spectroscopy for Ionic Liquids, IEEE Trans Nanobioscience, 2018 Oct, 17, 4, 387-393, doi: 10.1109/TNB.2018.2872535.

Cole K.S., Cole R.H., Dispersion and Absorption in Dielectrics. I. Alternating Current Characteristics, J. of Chemical Physics, 1941, 9, 341-351.

Emmert S., Wolf M., Gulich R. et al., Electrode Polarization Effects in Broadband Dielectric Spectroscopy, Eur. Phys. J. B 2011, 83, 157, https://doi.org/10.1140/ epjb/e2011-20439-8.

Gabriel C., Compilation of the Dielectric Properties of Body Tissues at RF and Microwave Frequencies, 1996, DOI: 10.21236/ada303903.

Gavdush A.A., Chernomyrdin N.V., Komandin G.A., Dolganova I.N., Nikitin P.V., Musina G.R., Katyba G.M., Kucheryavenko A.S., Reshetov I.V., Potapov A.A., Tuchin V.V., Zaytsev K.I., Terahertz Dielectric Spectroscopy of Human Brain Gliomas and Intact Tissues ex vivo: Double-Debye and DoubleOverdamped-Oscillator Models of Dielectric Response, Biomed. Opt. Express, 2021, 12, 69-83.

Grenier K., Dubuc D., Chen T., Artis F., Chretiennot T. et al., Recent Advances in Microwave-Based Dielectric Spectroscopy at the Cellular Level for Cancer Investigations, IEEE Transactions on Microwave Theory and Techniques, Institute of Electrical and Electronics Engineers, 2013, 61, 5, 2023-2030, ff10.1109/TMTT.2013.2255885ff. ffhal-00879581. 
Havelka D., Krivosudský O., Průša J., Cifra M., Rational Design of Sensor for Broadband Dielectric Spectroscopy of Biomolecules, Sensors and Actuators B: Chemical, 2018, 273, 62-69, https://doi.org/10.1016/j.snb.2018.05.124.

Kremer F., Dielectric Spectroscopy-Yesterday Today and Tomorrow, J. NonCrystalline, 305, 1, 1-9, Jul. 2002.

Laux E., Ermilova E., Pannwitz D., Gibbons J., Hölzel R., Bier F., Dielectric Spectroscopy of Biomolecules up to $110 \mathrm{GHz}$, Frequenz, 2018, 72, 3-4, 135 140, https://doi.org/10.1515/freq-2018-0010.

Li H., Multari C., Palego C., Ma X., Du X., Ning Y., Buceta J., Hwang J.C.M., Cheng X., Differentiation of Live and Heat-Killed E. Coli by Microwave Impedance Spectroscopy, Sensors and Actuators B: Chemical, 2018 February, 255, 2, 1614-1622.

Nasir N., Al Ahmad M., Cells Electrical Characterization: Dielectric Properties, Mixture, and Modeling Theories, Journal of Engineering, vol. 2020, Article ID 9475490, 17 pages, 2020, https://doi.org/10.1155/2020/9475490.

Nelson S.O., Agricultural Applications of Dielectric Spectroscopy, J. Microw. Power Electromagn. Energy, 2004, 39, 2, 75-85, doi: 10.1080/08327823.2004.11688510.

Qian W., Zhang Y., Chen W., Capturing Cancer: Emerging Microfluidic Technologies for the Capture and Characterization of Circulating Tumor Cells, Small, 2015 Aug 26, 11, 32, 3850-3872, doi: 10.1002/smll.201403658.

Schwan H.P., Electrical Properties of Tissue and Cell Suspensions*, Adv. Biol. Med. Phys. 1957, 5, 147-209.

Shiraga K., Suzuki T., Kondo N., Tajima T., Nakamura M., Togo H., Hirata A., Ajito K., Ogawa Y., Broadband Dielectric Spectroscopy of Glucose Aqueous Solution: Analysis of the Hydration State and the Hydrogen Bond Network, The Journal of Chemical Physics, 2015, 142, 23, 234504, https://doi.org/10.1063/1.4922482.

Souli M.P., Klonos P., Fragopoulou A.F. et al., Applying Broadband Dielectric Spectroscopy (BDS) for the Biophysical Characterization of Mammalian Tissues Under a Variety of Cellular Stresses, Int. J. Mol. Sci. 2017, 18, 4, 838, Published 2017 Apr 15. doi:10.3390/ijms18040838.

Stoneman M.R., Kosempa M., Gregory W.D., Gregory C.W., Marx J.J., Mikkelson W., Tjoe J., Raicu V., Correction of Electrode Polarization Contributions to the Dielectric Properties of Normal and Cancerous Breast Tissues at Audio/Radiofrequencies, Phys. Med. Biol. 2007 Nov. 21, 52, 22, 6589-6604, doi: 10.1088/0031-9155/52/22/003.

Turcan I., Olariu M.A., Dielectrophoretic Manipulation of Cancer Cells and Their Electrical Characterization, ACS Comb Sci. 2020 Nov 9; 22, 11, 554-578, doi: https://doi.org/10.1021/acscombsci.0c00109.

Wolf M., Gulich R., Lunkenheimer P., Loidl A., Broadband Dielectric Spectroscopy on Human Blood, Biochim Biophys Acta, 2011 Aug., 1810, 8, 727-40, doi: 10.1016/j.bbagen.2011.05.012. 


\section{SPECTROSCOPIA DIELECTRICĂ DE BANDĂ LARGĂ ȘI ROLUL SĂU ÎN CARACTERIZAREA CELULELOR BIOLOGICE}

(Rezumat)

Spectroscopia dielectrică de bandă largă este o metodă de a caracteriza materia din perspectiva parametrilor ei dielectrici, care variază în funcție de frecvența câmpului electromagnetic aplicat. În ultimii ani, alături de numeroasele sale utilizări, se remarcă o creștere a interesului pentru folosirea metodei în domeniile biomedicale, cu precădere pentru caracterizarea celulelor normale și tumorale. În acest context, acest studiu își propune să abordeze în prima parte bazele teoretice și modelele matematice care explică principiul de funcționare al spectroscopului de bandă largă. Ulterior, sunt detaliate avantajele şi limitările metodei, inclusiv dificultățile pe care cercetătorul le poate întâlni în cazul lucrului cu celule vii. În final sunt prezentate cele mai importante rezultate ştiințifice obținute pe culturi celulare normale şi patologice, fiind sugerate posibile direcții viitoare de cercetare. 